\title{
МЕТОДОЛОГІЧНІ ОСНОВИ ФОРМУВАННЯ ОРГАНІЗАЦЙНО-МЕТОДИЧНОЇ КОМПЕТЕНТНОСТІ МАЙБУТНІХ ФАХІВЦІВ СФЕРИ ОБСЛУГОВУВАННЯ
}

\section{С. В. Огуй}

Полтавський національний педагогічний університет імені В.Г. Короленка

\section{вул. Остроградського, 2, м. Полтава, 36000, Україна. E-mail: allmail@pnpu.edu.ua}

В дослідженні виділено основні методологічні підходи до формування організаційно-методичної компетентності майбутніх фахівців сфери обслуговування, здійснено обгрунтування компетентністного, діяльністного, особистісно-орієнтованого та праксеологічного підходів при вирішенні проблеми формування організаційнометодичної компетентності майбутніх фахівців ресторанного обслуговування. Акцентовано увагу на значенні організаційної компетентності у професійному становленні й конкурентоспроможності працівника на сучасному ринку праці. Визначено послідовні етапи технології педагогічного проектування професійних компетентностей як освітніх результатів навчання, до складу яких ми відносимо й організаційно-методичну компетентність майбутніх фахівців ресторанного обслуговування.

Ключові слова: організаційно-методична компетентність, фахівець сфери обслуговування, фахівець ресторанного обслуговування, методологічні підходи: компетентністний, діяльністний, особистісно-орієнтований та праксеологічний.

\section{МЕТОДОЛОГИЧЕСКИЕ ОСНОВЫ ФОРМИРОВАНИЯ ОРГАНИЗАЦИОННОЙ КОМПЕТЕНЦИИ БУДУЩИХ СПЕЦИАЛИСТОВ СФЕРЫ ОБСЛУЖИВАНИЯ}

\section{С. В. Огуй}

Полтавский национальный педагогический университет имени В.Г. Короленко

ул. Остроградского, 2, г. Полтава, 36000, Украина. E-mail: allmail@pnpu.edu.ua

В исследовании выделены основные методологические подходы к формированию организационнометодической компетентности будущих специалистов сферы обслуживания, осуществлено обоснование компетентностного, деятельностного личностно-ориентированного и праксеологического подходов при решении проблемы, связанной с формированием организационно-методической компетентности будущих специалистов ресторанного обслуживания. Акцентировано внимание на значении организационно-методической компетентности в профессиональном становлении и конкурентоспособности работника на современном рынке труда. Определены последовательные этапы технологии педагогического проектирования профессиональных компетенций как образовательных результатов обучения, в состав которых мы относим и организационно-методическую компетентность будущих специалистов ресторанного обслуживания.

Ключевые слова: организационно-методическая компетентность, специалист сферы обслуживания, специалист ресторанного обслуживания, методологические подходы: компетеностный, деятельностный, личностно-ориентированный и праксеологический.

АКТУАЛЬНІСТЬ РОБОТИ. Сучасний ринок праці, з його високою інноваційною динамікою, висуває нові вимоги до випускників навчальних закладів, в тому числі коледжів та технікумів. Серед основних вимог до випускників закладів вищої освіти, що готують фахівців сфери обслуговування виділяємо готовність до безперервної самоосвіти й підвищення професійної кваліфікації; наявність ділової комунікативності; уміння роботи в команді; активна діяльність у нестандартних і невизначених ситуаціях; здатність приймати відповідальні рішення; критичне мислення; самоменеджмент; володіння навичками роботи з різними джерелами інформації тощо. При цьому треба врахувати, що вимоги роботодавців $\epsilon$ не стільки щодо «знань», скільки щодо способів діяльності - «уміння», «здатність», «готовність». Отже, йдеться про особливі результати навчання, де знання виступають необхідними, однак недостатніми умовами для досягнення високої якості освіти. Невідкладність процесу реформування системи вищої освіти зумовлені різними чинниками. По-перше, керівники підприємств дедалі частіше піднімають питання про якість освітньої підготовки. Здебільшого випускники володіють на належному рівні репродуктивними знаннями й уміннями, але якісне виконання професійних обов'язків потребує донав- чання випускника безпосередньо на виробництві 3 витратами часу та коштів. Це зумовлено відсутністю конструктивної взаємодії між підприємствами та закладами вищої освіти. Вирішення даного питання можливе за умов об'єднання зусиль роботодавців, освітян і науковців задля перегляду змісту освітньопрофесійних програм, розроблення базових та професійних компетентностей для окремої з врахуванням сучасних тенденцій розвитку виробничих технологій та оновлення змісту діючих державних стандартів. По-друге, зовнішні та внутрішні економічні перетворення у сфері послуг посилили значення результативної діяльності суб'єктів освіти, що дає підстави визначати пріоритетним показником професіоналізму фахівця якість його роботи, готовність та здатність до виконання професійних функцій на робочому місці в реальних умовах. Відповідно до Національної доктрини розвитку освіти у XXI столітті забезпечення якості стає ключовою ідеєю, новою філософією освіти, потенціалом навчальних закладів у розкритті можливостей у сфері освітньої діяльності [1]. По-третє, якість професійної підготовки фахівця не стільки залежить від успішного відтворення ним теоретичних знань (знаннєвої складової професійної компетентності), скільки від виконання ним трудових функцій (діяльнісного компо- 
ненту), що визначають результати навчання, а також компетентності, які набуває випускник закладу вищої освіти та здатен продемонструвати після завершення навчання. Аналіз типових навчальних планів та програм спонукає до перегляду обсягів теоретичних знань і практичної підготовки майбутніх фахівців сфери обслуговування, оновлення навчальних програм 3 теоретичних предметів із включенням інноваційних методів навчання, ситуаційних завдань професійного спрямування тощо. По-четверте, сучасний ринок праці вимагає від випускника не лише глибоких теоретичних знань, а й здатності самостійно застосовувати їх у нестандартних, постійно змінюваних життєвих ситуаціях, переходу від суспільства знань до суспільства життєво-компетентних громадян [2]. Реалізація означених вище чинників передбачає формування організаційно-методичної компетентності майбутніх фахівців сфери обслуговування, як значимої та професійно-важливої особистісної якості на усіх ланках освітньої системи. Теоретико-методологічним підгрунтям процесу формування організаційно-методичної компетенції майбутніх фахівців виступає сукупність методологічних підходів, завдяки яким досліджуване педагогічне явище, внаслідок своєї складності й багатоаспектності, розглядається з різних позицій.

Метою нашого дослідження $\epsilon$ характеристика методологічних підходів у системі формування організаційно-методичної компетентності майбутніх фахівців сфери обслуговування як однієї з важливих особистісних якостей у професійній діяльності. Для реалізації поставленої мети ми проаналізували праці відомих науковців та дослідили процес формування організаційної й методичної компетентностей, а також працездатності майбутнього фахівця індустрії обслуговування в закладах вищої освіти.

МАТЕРІАЛ І РЕЗУЛЬТАТИ ДОСЛІДЖЕНЬ. Вітчизняні та зарубіжні науковці визначають безліч підходів у системі формування професійної готовності майбутніх фахівців. У дослідженнях українських вчених (Л. Долинська, Л. Карамушка, М. Корольчук, О. Креденцер, С. Максименко, С. Миронець) висвітлено і практичні, і теоретичні питання - методологічні підходи, визначення понять, шляхи формування професійних якостей тощо. Зарубіжні науковці (В. Бодров, Л. Виготський, Д. Ельконіна, Р. Мартенес, Л. Меркур'єва, А. Леонтьева, С. Павлютенков, С. Рубінштейн, М. Савіна, А. Сазонова, В. Симоненко, О. Філь, С. Чистякова) на перший план висувають діяльністний підхід.

Аналізуючи праці вітчизняних та закордонних науковців ми концентрували наше дослідження на обгрунтуванні компетентністного, діяльністного, особистісно-орієнтованого та праксеологічного підходів при вирішенні проблеми формування організаційно-методичної компетентності майбутніх фахівців сфери обслуговування.

Компетентністний підхід до оновлення освіти в Україні започаткований у 2013 році, орієнтований на загальноєвропейські процеси реформування та розвитку освіти та державно прийнятий і схвалений рядом нормативних документів, зокрема Національною стратегією розвитку освіти в Україні на період до 2021 рік [3].
Компетентність виникла 3 потреби в адаптації людини до занадто мінливих умов існування, - зазначає О. Пометун [4]. На думку В. Радкевич, ключові компетентності - це загальні здібності й уміння, що дають змогу особі розуміти ситуацію, досягати успіху в особистісному й професійному житті набувати соціальної самостійності та забезпечувати ефективну професійну взаємодію. Ключові компетентності грунтуються на головних цілях загальної і професійної освіти тих, хто навчається, їхньому соціальному й особистісному досвіді, а також на основних видах діяльності [2]. Серед ключових компетентностей науковці виділяють:

1) навчальну, що передбачає дві центральні ідеї: інтелектуальний розвиток особистості та ії здатність учитися впродовж життя;

2) підприємницьку, що передбачає володіння засобами, що майбутньому фахівцеві надають можливість ефективно організувати особисту та колективну трудову й підприємницьку діяльність;

3) соціальну, яка передбачає володіння сукупністю засобів, що забезпечують можливість особистості взаємодіяти з різними соціальними групами та соціальними інститутами суспільства;

4) громадянську, що передбачає формування здатності захищати та піклуватись про відповідальність, права, інтереси та потреби людини і громадянина, держави і суспільства;

5) здоров'язбережувальну, що передбачає набуття студентами характеристик i властивостей, спрямованих на збереження фізичного, соціального, психічного і духовного здоров'я, свого та оточення;

6) компетентності з інформаційних та комунікаційних технологій передбачають здатність студента орієнтуватися в інформаційному просторі, володіти й оперувати інформацією відповідно до потреб ринку праці;

7) культурну, що передбачає здатність жити та взаємодіяти 3 іншими в умовах полікультурного суспільства, керуючись національними та загальнолюдськими цінностями;

8) професійну, яка спрямована на засвоєння та оволодіння професійно значущих знань, умінь та навичок, розвиток професійної самосвідомості.

Кожна 3 ключових компетентностей передбачає засвоєння особистістю не окремих непов'язаних один 3 одним елементів знань і умінь, а оволодіння комплексною процедурою, в якій кожному виділеному напряму ії набуття відповідає сукупність освітніх компонентів, що мають особистіснодіяльнісний характер [5].

Технологія педагогічного проектування ключових компетентностей як освітніх результатів навчання включає такі послідовні етапи:

1) визначення переліку ключових компетентностей для фахівців ресторанного обслуговування;

2) перелік компетенцій для даних фахівців;

3) розроблення навчально-методичного забезпечення для формування ключових компетентностей;

4) відбір педагогічних технологій;

5) визначення методів і критеріїв оцінювання рівня сформованості ключових компетентностей. 
Більшість публікацій, які висвітлюють проблему компетентнісного підходу, присвячено розгляду ключових компетентностей, а професійним та предметним компетентностям ученими приділено недостатньої уваги, ці проблеми знаходяться в стані розробки.

Виділяючи діяльністний niдхід у формуванні компетентностей майбутніх фахівців сфери обслуговування ми спробували визначити складові професійної компетентності як важливого особистісного утворення, важливого та необхідного для успішного здійснення професійної діяльності.

Професійні або фахові компетентності відображають специфіку професійної діяльності у певній галузі чи сфері. Професійна компетентність - головний критерій, за яким оцінюється персонал будьякої організації чи компанії. Це здатність фахівця вирішувати певний клас професійних завдань у комплексному їх представленні. У формальному розумінні під компетентністю можна розуміти опис вимог до особистісних, професійних, когнітивних якостей, яким повинен відповідати фахівець певної сфери діяльності [6].

До професійних компетентностей майбутніх фахівців сфери обслуговування відносимо такі:

- теоретико-технологічна - наявність системи професійних знань, спроможність інтеграції знань у нових ситуаціях, здатність до ефективних розв'язань традиційних та нетрадиційних завдань,самостійно одержувати інформацію, постійно підвищувати освітній рівень;

- виробничо-технологічна - здатність планувати технологічні процеси, використовувати досвід інших, володіння інформаційними технологіями;

- соціально-комунікативна - готовність до взаєморозуміння та взаємодії у комунікації та стосунках, здатність до обговорення та прийняття спільних рішень, здатність брати відповідальність за їх реалізацію на себе, здатність уникати конфліктів, толерантно розв'язувати їх між іншими учасниками виробничого колективу;

- організаційно-методична - професійна мобільність, здатність проектувати власну діяльність та діяльність співробітників, враховуючи потреби клієнтів, творчий підхід до роботи з колективом, здатність суміщення власних інтересів та потреб підприємства і суспільства, здатність до постійного підвищення освітнього рівня, потреба в актуалізації й реалізації власного потенціалу, здатність точно і коректно передавати знання, формулювати вимоги, завдання підлеглим тощо.

Аналіз наукових праць свідчить, що процес формування організаційно-методичної компетентності майбутніх фахівців сфери обслуговування досліджено недостатньо. Зокрема, потребують обгрунтування методологічні підходи до системи формування організаційно-методичної компетентності майбутніх фахівців готельно-ресторанного бізнесу. Одні$\epsilon ю$ із проблем $\epsilon$ те, що закладам готельноресторанного бізнесу не вистачає добре підготовлених фахівців, які б уміли застосовувати отримані теоретичні знання на практиці. Очевидним $є$ те, що лише фахівець з високим рівнем професіоналізму зможе бути конкурентоспроможним в сфері готельно-ресторанного бізнесу, здатним до активної роботи, глибокого аналізу ринкової ситуації, постійного самовдосконалення. Як джерело професійної підготовки, оновлення знань і перепідготовки кадрів важливо систематично враховувати тенденції, які виникають на ринку праці, а також у сферах економіки, права, готельного-ресторанного господарства, менеджменту тощо.

Серед першочергових завдань, що висуваються до освітніх закладів, є забезпечення професійної підготовки фахівців нового типу, як повинні бути розумними, вправними та здатними у разі необхідності швидко перекваліфікуватися чи змінити професію, володіти професійною гнучкістю та мобільністю. Серед інших обов'язкових елементів кваліфікації сучасного працівника Г. Щокін виділяє належний рівень загальної освіти, широку професійну підготовку і високий культурно-технічний рівень, уміння швидко поновлювати та поповнювати знання.

Сучасний фахівець практично у будь-якій сфері діяльності повинен володіти здатністю до абстрактного мислення, до роботи в творчих колективах, мати підготовку у сфері маркетингу, а також чітко уявляти собі господарські, організаційні, соціальні та культурні аспекти застосування нових технологій [7].

У професійній педагогіці під поняттям «формування» розуміють процес становлення людини як соціальної істоти під впливом усіх факторів: природних, економічних, соціальних, культурних, екологічних, політичних, ідеологічних, психологічних тощо. Людина, яка вирішила працювати у сфері обслуговування, стати фахівцем і присвятити себе розвитку цієї галузі, проходить низку етапів професійного становлення. Кожен із цих етапів - це певний ступінь підготовки, що вимагає володіння необхідним обсягом знань, умінь, навичок, особистісних професійних якостей. Для реалізації змісту зазначених етапів виникає потреба розробити навчальнометодичний комплекс формування й розвитку професійних компетентностей фахівців ресторанного сервісу як складову професійної кваліфікації майбутнього робітника на основі сучасних педагогічних технологій. Основними завданнями такого навчального забезпечення $є$ : 1) розвиток комунікативної, психологічної та організаційно-методичної компетентностей фахівців ресторанного сервісу; 2) підвищення мотивації студентів технікумів і коледжів до здобуття обраної професії; 3) розвиток позитивного ставлення фахівця до самого себе й обраної ним професії; 4) розвиток умінь і навичок планування власного майбутнього професійного життя.

Важливою педагогічною умовою формування професійних компетентностей фахівців сфери обслуговування $\epsilon$ поетапність їх формування через систему знань, умінь і навичок. Перший етап - ціннісно-змістовий, на якому відбувається формування і усвідомлення мотивів і цінностей майбутньої професійної діяльності, співпадає з вивченням теоретичних дисциплін. Другий етап - інформаційнокогнітивний, де пріоритетом є формування когнітивного компонента професійних компетентностей та інноваційними засобами виступають вивчення спе- 
ціальних дисциплін i проходження виробничих практик. Третій етап практично-технологічний, передбачає вивчення спецкурсів, які безпосередньо пов'язані 3 практичним освоєнням теоретичних знань, відбувається формування поведінкового та емоційно-вольового компонента професійних компетентностей.

Найважливішою рисою фахівця нової формації $€$ становлення організаційно-методичної компетентності. В iї основу покладений зміст практичної підготовки майбутнього фахівця ресторанної справи, організація процесу практичної підготовки майбутнього фахівця; обгрунтовано організаційнопедагогічні умови ефективного формування професійних умінь та методика формування професійних умінь майбутнього фахівця ресторанної справи. Вивчення особливостей професійної діяльності в закладах ресторанного господарства, динамічність та стрімкі зміни організаційних засад технічних та технологічних процесів виробництва продукції є складовими у визначенні основних підходів щодо вибору форм i методів професійно-практичної підготовки майбутніх фахівців ресторанної справи. Важливе значення у формуванні відповідних професійних умінь майбутнього фахівця ресторанної справи має його самостійна діяльність, спрямована на відпрацювання найважливіших складових майбутньої професії.

Організація навчально-виховного i навчальновиробничого процесу має здійснюватися за допомогою відповідних форм навчально-пізнавальної діяльності, що найбільшою мірою відтворюють реальні умови праці. На цій основі реалізується професійнопрактична діяльність студентів.

Реалізація принципу міждисциплінарних зв'язків зумовлює певні вимоги до процесу організації професійного навчання з урахуванням взаємозв'язку теоретичної і навчально-виробничої підготовки. Практична підготовка майбутнього фахівця ресторанної справи має передбачати застосування форм навчальнопізнавальної діяльності, які забезпечують творчий, пошуковий характер професійних дій. Формування комунікативних умінь професійного спілкування, моделювання у процесі підготовки реальних проблем та ситуацій дасть змогу розширити простір його професійної та соціальної взаємодії з галузевим середовищем. До речі, на практичні заняття й самостійну роботу доцільно відвести більшу частину навчального часу, оскільки ключові компетентності випускника проявляються не в репродуктивній, а у професійній діяльності і позначаються такими категоріями: вивчати, шукати, думати, співпрацювати, братись за справу, адаптовуватися тощо. Закріплення набутих компетенцій варто проводити за допомогою бесіди, діалогу, тестування, ситуативних вправ, ділових ігор, творчих проектів тощо.

Головною відмітною рисою компетентнісної освіти є підсилення суб'єктності (індивідуальності) здобувачів вищої освіти, надання навчанню особистісної значущості. Науковці підкреслюють при цьому важливість опори на ціннісні орієнтації студентів.

Особисто-орієнтований підхід до формування організаційно-методичної компетентності сприяе розв’язанню проблеми розвитку індивідуальності кожного студента. Для вирішення такої проблеми необхідне створення такого професійно орієнтованого навчального середовища, яке б забезпечувало свободу вибору індивідуальної освітньої траєкторії та відкривало можливості для самостійної роботи студентів, їх самовизначення та самореалізації. При цьому необхідна побудова професійного навчання у вигляді розв'язання ланцюга професійно орієнтованих задач-ситуацій. На думку І. Зимньої, психологопедагогічні проблеми розвитку сучасної освіти необхідно розглядати на основі особистісно діяльнісного підходу, згідно якого у центрі освітнього процесу знаходиться студент. формування його особистості відбувається засобами конкретного навчального предмета; б) навчальний процес передбачає організацію і управління навчальною діяльністю учнів (студентів), спрямованою на їх усебічний розвиток i освоєння ними предметних знань [8-10].

Особистісно-орієнтована технологія навчання переводить на активну позицію всіх учасників навчального процесу. I викладач, і студент виступають суб'єктами навчання, мають право обирати траєкторію навчання, враховуючи можливості та бажання студента. Таким чином навчання переходить в площину самоосвіти, де викладач виконує роль консультанта (тьютора), який координує та спрямовує навчальну діяльність студентів, у формі діалогового спілкування.

Зміст навчання виступає засобом розвитку особистості студента та узгоджується 3 процесом його засвоєння, визначає механізми самоорганізації та освіти, розкриває кінцевого результат освітнього процесу. Реалізація особистісно-орієнтованого навчання передбачає поєднання традиційних методів 3 інноваційними (проблемне та перевернуте навчання, евристична бесіда, інтерактивні методи) з опорою на суб'єктивний досвід студентів.

Для реалізації процесу формування організаційно-методичної компетентності особистісноорієнтоване навчання дає ряд переваг: по-перше, потреба у засвоєнні знань дозволяє реалізувати у майбутньому професійну мобільність; по-друге, відбувається повне засвоєння соціального досвіду та набуття особистісного досвіду, що формує здатність проектувати власну діяльність та діяльність співробітників, здатність суміщення власних інтересів та потреб підприємства і суспільства; по-третє, набуття навичок творчої діяльності та ціннісних відносин впливають на формування здатності до постійного підвищення освітнього рівня, потреба в актуалізації й реалізації власного потенціалу, сприяють реалізації творчого підходу до роботи з колективом та інші переваги, яких набагато більше ніж недоліків.

Розгляд різних методологічних підходів до проблеми формування організаційно-методичної компетентості майбутніх фахівців сфери обслуговування підвів нас до розуміння необхідності перенесення результатів дослідження в практичну площину, визначення умов їх практичного застосування. На цьому будується праксеологічний підхід до розв'язання науково-прикладних досліджень.

У педагогічній практиці праксеологічний підхід тлумачиться як результативність навчального про- 
цесу або ефективна діяльність. Для того щоб досягти бажаного результату навчання необхідно спланувати, організувати та здійснити доцільно організовану, продуктивну, логічно-послідовну діяльність 3 дотриманням норм та вимог. Сутність праксеологічного підходу до процесу формування організаційнометодичної компетентності майбутніх фахівців сфери обслуговування полягає в організації навчальнометодичної діяльності студента 3 позиції доцільності (відповідності наміченій меті), раціональності (осмисленості та обгрунтованості), ефективності (приведення до потрібного результату). Розглядаючи комплексну складова професійної компетентності таку як організаційно-методична компетентність варто розмежувати іiі окремі, але взаємопов'язані, компоненти: організаційний та методичний.

Організаційний компонент компетентності збагачує особистість такими якостями як відповідальність, дисциплінованість, пунктуальність, а також навичками самоорганізації й взаємодії з суб'єктами навчальної, а у майбутньому професійної діяльності. Методичний компонент об'єднує у собі зміст, форми та методи (технології) професійної діяльності. Поєднання цих компонент в єдину комплексну компетентність вважаємо доцільним, оскільки саме доцільна ефективна організація забезпечує максимально продуктивну методично-сплановану професійну діяльність.

Формування організаційно-методичної компетентності майбутніх фахівців сфери обслуговування у першу чергу покладається на педагогів та майстрів виробничого навчання закладів професійної освіти. Необхідними умовами є бажання і готовність педагогів технікумів і коледжів до інноваційної діяльності, модернізації змісту, їх готовності до особистісно-професійного саморозвитку; підтримувати сприятливий психологічний клімат у колективі, усвідомлювати важливістю й необхідність підготовки компетентного фахівця, а не просто особи, яка володіє деякими теоретичними знаннями та практичними вміннями.

Пріоритетність професійних компетентностей зумовлена й функціями, які вони виконують у життєдіяльності кожної людини, а саме: формування в особистості здатності навчатися і самонавчатися; забезпечення майбутнім фахівцям здатності до гнучкості та професійної мобільності; підвищення соціальної активності, конкурентоспроможності випускника в умовах ринку праці.

Таким чином, виокремлення 3 переліку професійних компетентностей організаційно-методичної та розроблення навчально-методичного комплексу щодо формування означеної компетентності майбутніх фахівців сфери ресторанного обслуговування сприятиме усуненню їх дублювання у процесі набуття інших професійно-значимих компетнтностей $\mathrm{i}$ забезпечить їхнє взаємодоповнення та інтеграцію задля якісної підготовки висококваліфікованих робітників сфери обслуговування.

ВИСНОВКИ. В основі процесу формування професійних компетентностей студентів лежить спільне завдання - розвиток здатності до самоосвіти, професійної мобільності та активності, спрямування діяльності майбутніх фахівців на досягнення якісного результату, розвиток здатності до самореалізації. Отже, професійна підготовка за змістом i формами іiї організації та проведення має бути процесом, у якому формуванню професійним компетентностям необхідно приділяти таку саму увагу, як і оволодінню фаховими знаннями, уміннями та навичками. При цьому питома вага у формуванні професійних компетентностей у фаховій підготовці здебільшого належить організаційно-методичній компетентності, сутність якої полягає у підготовленості майбутніх фахівців сфери обслуговування до самостійного виконання професійних виробничих завдань, уміння оцінювати виконання праці, здатність самостійно здобувати нові знання й уміння; здатність до колективної діяльності і співробітництва 3 іншими працівниками, готовність до прийняття на себе відповідальності за результати своєї праці; готовність до постійного підвищення професійної майстерності та особистісних якостей, здатність до самомотивування, рефлексії, саморозвитку особистості в професійній діяльності.

\section{ЛІТЕРАТУРА}

1. Адаптивне управління розвитком професійної освіти: Колективна монографія. Г. В. Сльникова, О. О. Загіка, Г. Ю. Кравченко, І. С. Лапшина, Г. І. Лукьяненко, В. Е. Лунячек, Г. А. Полякова, В. С. Ульянова, Л. І. Фесик та ін. За заг. та наук. редакцією Г. В. Сльникової. Павлоград: ІМА-прес, 2016. 248 с.

2. Радкевич В. О. Компетентнісний підхід до розроблення Державних стандартів професійнотехнічної освіти. Проф.-тех. освіта. 2012. № 3. C. $8-10$.

3. Національна стратегія розвитку освіти в Україні на період до 2021 року [Електронний ресурс]. Режим http://zakon4.rada.gov.ua/laws/show/344/2013 доступу:

4. Пометун О. І. Дискусія українських педагогів навколо питань запровадження компетентнісного підходу в українській освіті. Компетентнісний підхід у сучасній освіті. Світовий підхід та украӥнські перспективи [під заг. ред. О. В. Овчарук]. К. : «K.I.C.», 2004. 112 c.

5. Ягупов В. В. Ключові компетентності: поняття, сутність, зміст, класифікація та вимоги до випускників професійно-технічної освіти. Вісник Дніпропетровського університету імені Альфреда Нобеля. Серія: Педагогіка $і$ психологія. Педагогічні науки. 2015. № 1(9). С. 193-199.

6. Щокин Г. В. Теорія і практика управління персоналом: навч. посіб.: 2-е вид. Київ: МАУП, 2003. $280 \mathrm{c}$.

7. Довідник кваліфікаційних характеристик професій працівників [Електронний ресурс] / М-во праці та соц. політики України (Мінпраці та соцполітики) від 28.12.2001. - Режим доступу http://uazakon.com/document/spart20/inx20247.htm.

8. Зимняя И. А. Педагогическая психология: Учеб. пособие. М. : Логос, 2004. 384 с.

9. Гайовий I. I. Ефективність практичної підготовки фахівця ресторанної справи. Сучасні інформаціийні технологї та інноваційні методики навчання у підготовиі фахівиів: методологія, теорія, досвід, 
проблеми : зб. наук. пр. Редкол. І. А. Зязюн (голова) [та ін.]. К.-Вінниця : ТОВ фірма «Планер», 2009. Вип. 22. С. 143-149.

10. Шапран О. I. Компетентнісний підхід до організації педагогічної практики студентів. Гуманіт. вісн.
Cпец. вип. Педагогіка: зб. наук. пр. ПереяславХмельниц. держ. пед. ун-т ім. Григорія Сковороди. Т., 2012. Вип. 26. С. 354-358.

\section{METHODOLOGICAL BASIS OF FORMING ORGANIZATIONAL COMPETENCE OF FUTURE SPECIALISTS IN SERVICE INDUSTRY}

\section{S. Ohui}

Poltava V. G. Korolenko National Pedagogical University

vul. Ostrogradskogo, 2, Poltava, 36000, Ukraine. E-mail: allmail@pnpu.edu.ua

Purpose. The purpose of this research is to characterize the methodological approaches in the system of forming organizational and methodological competence of future specialists in service industry as one of the most important personal qualities in professional activity. Methodology. The research determines the main methodological approaches to forming organizational and methodological competence of future specialists in service industry and establishes the topicality of competence-based, personality-oriented activity, and praxeological approaches for solving the issue of forming organizational and methodological competence of future specialists in restaurant service. The relevance of organizational and methodological competence for the employee's professional development and competitive value in the present-day labour market is emphasized. Findings. Consecutive stages of pedagogical projection of professional competences as outcomes of educational process are distinguished, including organizational and methodological competence of future specialists in restaurant service. The necessity of implementing personality-oriented educational environment in a harmonious combination with group and collective forms of learning is validated. The priority of the activity component in the structure of professional competences is proven, as it facilitates the application of profound theoretical knowledge for the solution of work problems and in non-standart, constantly changing life situations. Practical value. The results of this research are of use for the development of competence-based pedagogical technologies. Conclusions. The research proves the importance of organizational and methodological competence for the swift adaptation of new specialists in restaurant service to highly changeable work conditions and for the ensuring effective professional interaction between all parties involved in service industry.

Key words: organizational and methodological competence, specialist in service industry, specialist in restaurant service, methodological approaches: competence-based, personality-oriented, activity, and praxeological.

\section{REFERENCES}

1. Yelnikova, H. V. (2016), Adaptyvne upravlinnia rozvytkom profesijnoyi osvity: Kolektyvna monografiya [Adaptational management of the development of vocational education], Pavlohrad, IMA-press.

2. Radkevych, V. O. (2012), Competence-based approach to the development of the State standards of vocational education, Profesijno-tekhnichna osvita [Vocational education], 3, pp. 8-10.

3. Natsionalna strategiya rozvytky osvity v Ukrayini na period do 2021 roku [National strategy for the development of education in Ukraine for the period until 2021] (2013), [Online], available at: https://zakon4.rada.gov.ua/laws/show/344/2013 [Accessed on April 3rd, 2019].

4. Ponometon, O. I. (2004), Dyskusiia ukrainskykh pedahohiv navkolo pytan zaprovadzhennia kompetentnisnoho pidkhodu $\mathrm{v}$ ukrainskii osviti [Discussion of Ukrainian Teachers on Issues of Implementing a Competency Approach in Ukrainian Education], Kompetentnisnyi pidkhid u suchasnii osviti. Svitovyi pidkhid ta ukrainski perspektyvy [Competency approach in modern education. Global approach and Ukrainian perspectives]. Kiev, "K.I.S.".

5. Yahypov, V. V. (2015), Key competences: notion, essence, content, classification and requirements for the graduates of vocational institutions, Visnyk Dnipropetrovskoho universytetu imeni Alfreda Nobelia. Seriya: Pedahohika $i$ psykholohiya. Pedahohichni nauky [Dnipropetrovsk Alfred Nobel University Journal. Se- ries: Pedagogy and psychology. Pedagogical sciences], 1(9), pp. 193-199.

6. Schokyn, H. V. (2003), Teoriya i praktyka upravlinnia personalom [Theory and practice of personnel management], 2nd ed. Kyiv, Interregional Academy of Personnel Management.

7. Ministry of Labor and Social Policy of Ukraine (2001), Dovidnyk kvalifikatsijnykh kharakterystyk profesij pratsivnykiv [Directory of qualification characteristics of workers' professions], [Online], available at: http://uazakon.com/document/spart20/inx20247.htm [Accessed on April 3rd, 2019].

8. Zimniaya, I. A. (2004), Pedagogicheskaya psikhologiya [Pedagogical psychology], Moscow, Logos.

9. Hayovy, I. I. (2009), Efektyvnist praktychnoyi pidhotovky fakhivtsia restorannoyi spravy [Effectiveness of practical training of a restaurant service specialist]. Suchasni informatsijni tekhnologiyi na innovatsijni metodyky navchannia $u$ pidhotovtsi faknivtsiv: metodolohiya, teoriya, dosvid, problemy [Modern information technologies and innovative methods of educating and training specialists: methodology, theory, experience, problems], 22, 143-149.

10. Shapran, O. I. (2012), Competence-based approach to the organization of students' pedagogical practice, Humanitarny visnyk. Spetsialny vypusk. Pedahohika [Humanities journal. Special issue. Pedagogy], 26, pp. 354-358. 